\title{
Zgrzewanie elektrooporowe gazociągów polietylenowych w ujemnych temperaturach otoczenia
}

\begin{abstract}
W artykule opisano metodykę zgrzewania elektrooporowego w ujemnych temperaturach otoczenia, polegającą na ustaleniu parametrów wstępnego nagrzewania poprzez zastosowanie obniżonego napięcia zgrzewania w określonym czasie. Celem tego działania było uzyskanie dodatniej temperatury kształtki i rury, tak aby można było rozpocząć właściwy proces zgrzewania. Opracowaną metodykę zweryfikowano doświadczalnie.
\end{abstract}

Słowa kluczowe: gazociąg, rury polietylenowe, zgrzewanie elektrooporowe, nagrzewanie wstępne.

\section{Electrofusion welding of polyethylene gas pipelines in sub-zero temperatures}

The paper describes the developed method of electrofusion welding in sub-zero ambient temperatures, consisting of the setting of preheating parameters taken by applying a reduced welding voltage at a given time. This process was supposed to cause positive temperature of the fitting and the pipe so that the proper welding process could be started. The developed methodology was verified experimentally.

Key words: gas pipeline, polyethylene pipes, electrofusion welding, pre-heating.

\section{Wstęp}

W Polsce przy projektowaniu, budowie i przebudowie sieci gazowych stosuje się regulacje prawne zawarte w rozporządzeniu Ministra Gospodarki z dnia 26 kwietnia 2013 roku w sprawie warunków technicznych, jakim powinny odpowiadać sieci gazowe i ich usytuowanie [4]. W rozporządzeniu tym $\mathrm{w} \S 4$ podano wymaganie, aby projektować, budować i dokonywać przebudowy sieci gazowej w sposób zapewniający jej bezpieczne użytkowanie i utrzymanie oraz transport gazu ziemnego w ilościach wynikających z bieżącego i planowanego zapotrzebowania na niego. Do budowy gazociągów rozporządzenie dopuszcza takie materiały jak stal i polietylen. Ze względu na maksymalne ciśnienie robocze (MOP) dla gazociągów wykonanych z polietylenu wprowadzono ograniczenie do 1,0 MPa. Budowa gazociągów powyżej tego ciśnienia realizowana jest wyłącznie z rur stalowych [3].

$\mathrm{W} \S 30$ pkt 1 rozporządzenia podano wymagania dotyczące jakości rur i kształtek polietylenowych, metody łączenia elementów polietylenowych, jak również wymagania dotyczące połączeń zgrzewanych. Określono, że powinny one spełniać wymagania zawarte w Polskich Normach dotyczących syste- mów przewodów rurowych z tworzyw sztucznych do przesyłania paliw gazowych oraz systemów dostaw gazu. Wymagania funkcjonalne dotyczące sieci gazowych z polietylenu znajdują się w normie: PN-EN 12007-2:2013-02 Infrastruktura gazowa. Rurociagi o maksymalnym ciśnieniu roboczym do 16 bar włącznie. Część 2: Szczegółowe wymagania funkcjonalne dotyczace polietylenu (MOP do 10 bar włącznie) [10]. Określa ona zakres stosowania rur polietylenowych do rozprowadzania gazu. Zebrano tu wymagania dotyczące budowy sieci gazowych z polietylenu oraz zawarto kryteria oceny jakości połączeń zgrzewanych doczołowo i elektrooporowo [2].

Celem przedstawionej pracy było opracowanie metodyki zgrzewania elektrooporowego rur PE w sytuacjach awaryjnych przy ujemnych temperaturach otoczenia. W związku z tym opracowano założenia do metodyki zgrzewania elektrooporowego w ujemnych temperaturach otoczenia, polegającej na ustaleniu parametrów wstępnego nagrzewania poprzez zastosowanie obniżonego napięcia zgrzewania w określonym czasie. Proces ten miał powodować uzyskanie dodatniej temperatury kształtki i rury, tak aby można było rozpocząć właściwy 
proces zgrzewania. Parametry nagrzewania wstępnego wyznaczono doświadczalnie i stanowiły one podstawę do opracowania procedury zgrzewania, która mogłaby być wykorzystywana w warunkach eksploatacyjnych.

Zgrzewanie elektrooporowe elementów sieci gazowej może odbywać się w temperaturach powyżej $0^{\circ} \mathrm{C}$ [7]. W temperaturach ujemnych dopuszczalne jest zgrzewanie po zastosowaniu namiotu ochronnego i ogrzewaniu jego wnętrza.

Ze względu na niski współczynnik przewodzenia ciepła polietylenu [5] proces ten może trwać relatywnie długo, zwłaszcza dla rur i kształtek o dużych średnicach i grubościach ścianek.

W sytuacjach awaryjnych, gdy dojdzie do uszkodzenia gazociągu polietylenowego, wymagane jest podjęcie natychmiastowych działań naprawczych. Sytuacja komplikuje się, gdy stanie się to $\mathrm{w}$ temperaturach ujemnych otoczenia. Wówczas do zamknięcia przepływu gazu nie można wykorzystać techniki zaciskania ze względu na możliwość uszkodzenia rury PE [1]. W takim przypadku istnieje możliwość zastosowania techniki zamykania przepływu gazu, np. przez balonowanie. Wymaga to jednak wykonania połączenia zgrzewanego elektrooporowo odpowiednią kształtką służącą do montażu kolumny do balonowania. Ustawianie namiotu i ogrzewanie ciepłym powietrzem łączonych elementów znacznie wydłuża proces usuwania awarii. Opracowanie metodyki zgrzewania elektrooporowego w ujemnych temperaturach otoczenia pozwoliłoby na skrócenie czasu usunięcia awarii.

W ramach pracy zaplanowano wykonanie połączeń zgrzewanych elektrooporowo w temperaturze $-10^{\circ} \mathrm{C}$ dla różnych kształtek polietylenowych. Były to kształtki mufowe polskiego producenta z polietylenu klasy PE 100 o średnicach zewnętrznych $63 \mathrm{~mm}$ i $90 \mathrm{~mm}$, w szeregu wymiarowym SDR 11, które wraz z rurami polietylenowymi klasy PE 100 i PE 100 RC w szeregach wymiarowych SDR 11 i SDR 17,6 stanowiły materiał do wykonania połączeń zgrzewanych elektrooporowo.

Kontrola temperatury w procesie wstępnego ogrzewania łączonych rur i kształtek miała dostarczyć informacji, czy przy założonych parametrach (czas i napięcie zgrzewania) wystąpiło ogrzanie tych elementów do temperatury dodatniej. Ze względu jednak na niebezpieczeństwo zwarcia uzwojenia drutu oporowego kształtki czujnikiem temperatury nie był możliwy pomiar temperatury bezpośrednio w strefie zgrzewania. W związku z tym założono, że pomiar temperatury będzie prowadzony w połowie strefy zgrzewania $L_{2}$, a więc w połowie grubości ścianki zgrzewanych elementów (kształtki i rury). Temperatura była również monitorowana dla procesu zgrzewania w warunkach określonych przez producenta kształtki
Tablica 1. Obliczone czasy wstępnego nagrzewania

\begin{tabular}{|c|c|c|c|c|c|}
\hline \multicolumn{2}{|c|}{ ształtka PE } & \multicolumn{2}{|c|}{ Rura } & \multirow{2}{*}{$\begin{array}{c}\text { Napięcie } \\
\text { wstępnego } \\
\text { nagrzewania }\end{array}$} & \multirow{2}{*}{$\begin{array}{c}\text { Czas } \\
\text { nagrzewania } \\
\text { wstępnego }\end{array}$} \\
\hline $\begin{array}{l}\text { Inica } \\
\operatorname{trzna} d_{n}\end{array}$ & SDR & $\begin{array}{c}\text { grubość } \\
\text { ścianki } e_{n}\end{array}$ & SDR & & \\
\hline & & {$[\mathrm{mm}]$} & & [V] & {$[\mathrm{s}]$} \\
\hline & 11 & 5,8 & 11 & 12 & 26 \\
\hline & 11 & 8,2 & 11 & 12 & 76 \\
\hline 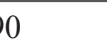 & 11 & 5,2 & 17,6 & 12 & 65 \\
\hline
\end{tabular}

w celu porównania jej z temperaturą uzyskaną podczas zgrzewania w warunkach normalnych.

Na początku zostały wykonane zgrzewy kontrolne w temperaturze otoczenia $23^{\circ} \mathrm{C}\left( \pm 2^{\circ} \mathrm{C}\right)$, zgodnie z zaleceniami producenta kształtek. W trakcie wykonywania zgrzewów mierzono i rejestrowano wartości temperatur zarówno w kształtce, jak i rurze. Zmierzona temperatura w połowie grubości ścianki rury i kształtki stanowiła odniesienie dla temperatury mierzonej w takim samym położeniu czujników podczas zgrzewania w ujemnej temperaturze otoczenia, po uprzednim nagrzewaniu wstępnym. Założono, że porównywalne wartości temperatury będą świadczyć o podobnej temperaturze w strefie zgrzewu, tj. między powierzchnią zewnętrzną rury a powierzchnią wewnętrzną kształtki w obszarze uzwojenia drutu oporowego. Zapewnienie właściwej temperatury w strefie zgrzewania jest podstawowym warunkiem uzyskania połączenia zgrzewanego rur i kształtki.

Przed przystąpieniem do wykonania zgrzewu w temperaturze $-10^{\circ} \mathrm{C}$ sprawdzone zostały obliczone wartości czasu nagrzewania wstępnego, które miały zagwarantować uzyskanie dodatniej temperatury w obszarze sięgającym do połowy grubości ścianki rury i kształtki.

Jako że w wyliczonych czasach nagrzewania wstępnego w nagrzewanych elementach nie została osiągnięta temperatura $>0^{\circ} \mathrm{C}$, czas nagrzewania wstępnego został wyznaczony doświadczalnie.

W dalszej kolejności wykonano zgrzewy w temperaturze $-10^{\circ} \mathrm{C} \mathrm{z}$ ustalonym czasem nagrzewania wstępnego przy obniżonym napięciu zgrzewania (12 V), a następnie, bezpośrednio po jego zakończeniu i zaprogramowaniu zgrzewarki, wykonano zgrzewy przy standardowych parametrach, tj. napięciu zgrzewania 39,5 V oraz w czasie zgrzewania zaleconym przez producenta kształtki. Cały proces zgrzewania był na bieżąco rejestrowany. Oprócz rejestracji temperatury monitorowane było również napięcie zgrzewania oraz natężenie prądu w celu stwierdzenia, czy w procesie zgrzewania nie nastąpiło np. zwarcie uzwojenia drutu oporowego, które mogłoby zakłócić proces zgrzewania. Wyniki przeprowadzonych pomiarów zamieszczono w tablicach 2-10. 


\section{Analiza wyników}

W przypadku kształtki $d_{n} 90$ zgrzewanej z rurami PE szeregu wymiarowego SDR 11 zaobserwowano, podczas kontroli temperatury w czasie zgrzewania w warunkach normalnych, że temperatury w kształtce i rurze są zróżnicowane - w kształtce są wyższe, a w rurze są niższe, co jest typowe dla procesu zgrzewania elektrooporowego. Może to wynikać z tego, że drut oporowy jest zatopiony w korpusie kształtki i ciepło w głąb kształtki przepływa szybciej niż w głąb rury, która oddzielona jest od grzejnika pewną przestrzenią powietrza. Wielkość tej przestrzeni zależeć będzie od średnicy wewnętrznej kształtki i zewnętrznej rury. Dodatkowo przestrzeń ta, tzw. luz pomiędzy rurą a kształtką, może być nierównomierna na obwodzie, co może być spowodowane owalnością kształtki, a przede wszystkim rury, dla której z reguły owalność jest znacznie większa. Potwierdzeniem tego mogą być wyniki pomiarów zamieszczone w tablicy 2.

Różnice temperatury kształtki i rury wynoszą od $7^{\circ} \mathrm{C}$ do $67^{\circ} \mathrm{C}$. Podobna prawidłowość wystąpiła $\mathrm{w}$ czasie zgrzewów wykonywanych $\mathrm{w}$ temperaturze $-10^{\circ} \mathrm{C}$ po uprzednim zastosowaniu nagrzewania wstępnego (tablica 3), przy czym w tym przypadku różnice temperatury wynosiły od $6,7^{\circ} \mathrm{C}$ do $71,7^{\circ} \mathrm{C}$. Dodatkowo mogły one wynikać z braku powtarzalności wykonania otworów służących do wprowadzenia czujników temperatury. Różnice w wielkości nawet kilku dziesiątych części milimetra mogą powodować znaczne różnice w uzyskiwanych wartościach temperatury.

W tablicy 3 przedstawiono wartości temperatury w kształtce i rurze uzyskiwane przy różnych czasach nagrzewania wstępnego prowadzonego w temperaturze $-10^{\circ} \mathrm{C}$. Dla obliczonego czasu nagrzewania wynoszącego $76 \mathrm{~s}$ temperatura w kształtce wynosiła $11^{\circ} \mathrm{C}$, a w rurze była $<0^{\circ} \mathrm{C}$ i wynosiła $-1,9^{\circ} \mathrm{C}$. Powodem tego mogła być, wymieniona we wcześniejszych rozważaniach, przestrzeń powietrza pomiędzy zewnętrzną powierzchnią rury a wewnętrzną powierzchnią kształtki, która nie została uwzględniona w opracowanej formule służącej do obliczenia wstępnego czasu nagrzewania.

W kolejnych próbach wartości czasów nagrzewania wstępnego zostały zwiększone i już przy czasie nagrzewania wynoszącym $80 \mathrm{~s}$ uzyskano dodatnie temperatury w kształtce $\left(14^{\circ} \mathrm{C}\right)$ i rurze $\left(0,5^{\circ} \mathrm{C}\right)$.
Stosując wyznaczoną wartość czasu nagrzewania wstępnego, tj. $80 \mathrm{~s}$, wykonano połączenia zgrzewane w temperaturze $-10^{\circ} \mathrm{C}$. Wyniki zamieszczone w tablicy 4 wskazują na stosunkowo dużą powtarzalność w otrzymywanych temperaturach w czasie nagrzewania wstępnego. Podczas zgrzewania już przy właściwym napięciu, tj. 39,5 V, i w czasie $180 \mathrm{~s}$ w końcowej fazie zgrzewania wartości uzyskanych temperatur w kształtce $\left(125,5 \div 150,7^{\circ} \mathrm{C}\right)$ były niższe od wartości temperatur $\left(129,5 \div 173^{\circ} \mathrm{C}\right)$ podczas zgrzewania w temperaturze otoczenia $23^{\circ} \mathrm{C}\left( \pm 2^{\circ} \mathrm{C}\right)$, co mogło wynikać z większej różnicy temperatury pomiędzy powierzchnią kształtki a oto-

Tablica 2. Zestawienie wartości temperatur w trakcie zgrzewania W warunkach normalnych $23^{\circ} \mathrm{C}\left( \pm 2^{\circ} \mathrm{C}\right)$ : mufa elektrooporowa $d_{n} 90$, SDR $11+\operatorname{rura} d_{n} 90$, SDR $11, e_{n} 8,2$

\begin{tabular}{|l|c|c|c|c|}
\hline \multicolumn{2}{|c|}{ Numery zgrzewu próbnego } & 1 & 2 & 3 \\
\hline \multicolumn{2}{|l|}{ Temperatura otoczenia $\left[{ }^{\circ} \mathrm{C}\right]$} & 24,5 & 24,5 & 23,8 \\
\hline $\begin{array}{l}\text { Temperatura przed procesem } \\
\text { zgrzewania }\left[{ }^{\circ} \mathrm{C}\right]\end{array}$ & kształtka & 25,1 & 24,8 & 23,9 \\
\cline { 2 - 5 } & rura & 23,6 & 24,1 & 22,9 \\
\hline $\begin{array}{l}\text { Temperatura maksymalna } \\
\text { w trakcie zgrzewania }\left[{ }^{\circ} \mathrm{C}\right]\end{array}$ & kształtka & 135,7 & 173,0 & 129,5 \\
\cline { 2 - 5 } & rura & 103,5 & 106,0 & 122,5 \\
\hline Rzeczywista grubość ścianki rury $e_{n}[\mathrm{~mm}]$ & 8,6 & 8,5 & 8,5 \\
\hline
\end{tabular}

Tablica 3. Zestawienie temperatur w trakcie nagrzewania wstępnego od temperatury $-10^{\circ} \mathrm{C}$ do temperatury $0^{\circ} \mathrm{C}$ : mufa elektrooporowa $d_{n} 90$, SDR $11+\operatorname{rura} d_{n} 90, \mathrm{SDR} 11, e_{n} 8,2 \mathrm{~mm}$

\begin{tabular}{|l|c|c|c|c|}
\hline \multicolumn{2}{|c|}{ Numery zgrzewu próbnego } & 1 & 2 & 3 \\
\hline Temperatura przed procesem & kształtka & $-9,6$ & $-9,0$ & $-8,7$ \\
\cline { 2 - 5 } zgrzewania $\left[{ }^{\circ} \mathrm{C}\right]$ & rura & $-10,4$ & $-10,0$ & $-10,0$ \\
\hline $\begin{array}{l}\text { Temperatura maksymalna w trak- } \\
\text { cie wstępnego nagrzewania }\left[{ }^{\circ} \mathrm{C}\right]\end{array}$ & kształtka & 11,0 & 14,0 & 17,0 \\
\cline { 2 - 5 } & rura & $-1,9$ & 0,5 & 2,8 \\
\hline Czas nagrzewania wstępnego $[\mathrm{s}]$ & & 76 & 80 & 90 \\
\hline Rzeczywista grubość ścianki rury $e_{n}[\mathrm{~mm}]$ & 8,5 & 8,6 & 8,6 \\
\hline
\end{tabular}

Tablica 4. Zestawienie temperatur w trakcie zgrzewania W temperaturze $-10^{\circ} \mathrm{C}$ : mufa elektrooporowa $d_{n} 90$, SDR $11+$ rura $d_{n} 90$, SDR 11 , ścianki $e_{n} 8,2$

\begin{tabular}{|l|c|c|c|c|}
\hline \multicolumn{2}{|c|}{ Numery zgrzewu próbnego } & 1 & 2 & 3 \\
\hline \multirow{2}{*}{$\begin{array}{l}\text { Temperatura przed procesem } \\
\text { zgrzewania }\left[{ }^{\circ} \mathrm{C}\right]\end{array}$} & kształtka & $-9,0$ & $-8,5$ & $-8,8$ \\
\cline { 2 - 5 } & rura & $-10,0$ & $-10,0$ & $-9,9$ \\
\hline \multirow{2}{*}{$\begin{array}{l}\text { Temperatura maksymalna w trak- } \\
\text { cie wstępnego nagrzewania }\left[{ }^{\circ} \mathrm{C}\right]\end{array}$} & kształtka & 14,0 & 12,5 & 14,3 \\
\cline { 3 - 5 } & rura & 0,5 & 0,5 & 0,6 \\
\hline Czas nagrzewania wstępnego $[\mathrm{s}]$ & & $\mathbf{8 0}$ & $\mathbf{8 0}$ & $\mathbf{8 0}$ \\
\hline Temperatura maksymalna & kształtka & 150,7 & 145,7 & 125,5 \\
\cline { 2 - 5 } w trakcie zgrzewania $\left[{ }^{\circ} \mathrm{C}\right]$ & rura & 79,0 & 107,5 & 118,8 \\
\hline Czas zgrzewania $[\mathrm{s}]$ & & $\mathbf{1 8 0}$ & $\mathbf{1 8 0}$ & $\mathbf{1 8 0}$ \\
\hline Rzeczywista grubość ścianki rury $e_{n}[\mathrm{~mm}]$ & 8,5 & 8,6 & 8,6 \\
\hline
\end{tabular}


czeniem i ze zwiększonego studzenia. Podobnie wyglądało to $\mathrm{w}$ przypadku zmierzonych wartości temperatury rury. Zaobserwowane niższe wartości temperatury mogą świadczyć również o niższej temperaturze w strefie zgrzewu.

Z powyższego wynika, że w celu uzyskania powtarzalnych wartości temperatur należałoby zwiększyć ilość dostarczanej energii do kształtki podczas właściwego procesu zgrzewania - poprzez np. wydłużenie czasu zgrzewania i/lub zwiększenie napięcia zasilania uzwojenia kształtki, co pomimo zwiększonej wymiany ciepła z otoczeniem pozwoliłoby na uzyskanie właściwej temperatury w strefie zgrzewu.

Podczas wykonywania zgrzewów kształtki $d_{n} 63$ z rurami o szeregu wymiarowym SDR 11, podobnie jak w przypadku kształtki $d_{n} 90$ i rur o szeregu SDR 11, zaobserwowano, w czasie zgrzewania w warunkach normalnych, różnice $\mathrm{w}$ wartościach temperatury w kształtce i w rurze. Przyczynę ich powstania opisano dla poprzedniego przypadku.

W tablicy 6 przedstawiono wartości temperatury w kształtce i rurze uzyskiwane przy różnych czasach nagrzewania wstępnego prowadzonego od temperatury $-10^{\circ} \mathrm{C}$. Dla obliczonego czasu wynoszącego $26 \mathrm{~s}$ temperatura $\mathrm{w}$ kształtce wynosiła $4,1^{\circ} \mathrm{C}$, a w rurze $-7,3^{\circ} \mathrm{C}$. Wydłużenie czasu nagrzewania wstępnego do $50 \mathrm{~s}$ w dalszym ciągu nie spowodowało wzrostu temperatury w rurze powyżej $0^{\circ} \mathrm{C}$. Dopiero po czasie $60 \mathrm{~s}$ temperatura w kształtce była dodatnia i wynosiła $1,3^{\circ} \mathrm{C}$. Czas nagrzewania wstępnego został więc znacząco wydłużony w stosunku do wartości obliczonej (26 s), bo aż ponad dwukrotnie (60 s). Na tak dużą zmianę nie mogła mieć wpływu jedynie przestrzeń powietrza pomiędzy rurą i kształtką, jak w poprzednim przypadku, tj. dla rury i kształtki $d_{n} 90$ SDR 11. Należy tutaj wziąć pod uwagę grubość warstwy materiału rury znajdującego się między powierzchnią czujnika temperatury a wewnętrzną powierzchnią rury, na którą oddziaływała bezpośrednio temperatura otoczenia, $\mathrm{tj} .-10^{\circ} \mathrm{C}$. Dla rury $d_{n} 90$ SDR 11 wynosiła ona w przybliżeniu około 2,6 mm, a dla rury $d_{n} 63$ SDR 11 już tylko $1,5 \mathrm{~mm}$. Powodowało to, że ciepło od rury było oddawane do otoczenia szybciej i czas uzyskania temperatury rury powyżej $0^{\circ} \mathrm{C}$ musiał być dłuższy.

Dla wyznaczonej wartości czasu nagrzewania wstępnego, tj. $60 \mathrm{~s}$, wykonano połączenia zgrzewane $\mathrm{w}$ temperaturze $-10^{\circ} \mathrm{C}$. $\mathrm{W}$ tym przypadku podczas zgrzewania przy właściwym napięciu, tj. 39,5 V, i w czasie $120 \mathrm{~s}$ w końcowej fazie zgrzewania wartości uzyskanych temperatur w kształt- ce $\left(169,7 \div 180,0^{\circ} \mathrm{C}\right)$ były wyższe od wartości temperatur $\left(147,0 \div 170,0^{\circ} \mathrm{C}\right)$ otrzymywanych podczas zgrzewania w temperaturze otoczenia $23^{\circ} \mathrm{C}\left( \pm 2^{\circ} \mathrm{C}\right)$. Różnica ta mogła wynikać $\mathrm{z}$ umiejscowienia czujników temperatury. Podczas prowadzenia procesu zgrzewania w temperaturze ujemnej mogły one być usytuowane bliżej grzejnika. Uzyskanie powtarzalności w wykonywaniu otworów w kształtce było dużo trudniejsze niż w rurze ze względu na jej nierównomierny kształt, wynikający ze zróżnicowanej grubości ścianki nad strefą zgrzewania. Porównując natomiast wartości temperatury uzyskiwane w rurach, zaobserwowano już niższe jej wartości temperatury w czasie zgrzewania w temperaturze $-10^{\circ} \mathrm{C}$ od wartości uzyskiwanych podczas zgrzewania w temperaturze $23^{\circ} \mathrm{C}\left( \pm 2^{\circ} \mathrm{C}\right)$.

Tablica 5. Zestawienie wartości temperatur w trakcie zgrzewu W warunkach normalnych: $23^{\circ} \mathrm{C}\left( \pm 2^{\circ} \mathrm{C}\right)$, mufa elektrooporowa $d_{n} 63$, SDR $11+\operatorname{rura}_{n} 63$, SDR 11 i $e_{n} 5,8$

\begin{tabular}{|l|c|c|c|c|}
\hline \multicolumn{2}{|c|}{ Numery zgrzewu próbnego } & 1 & 2 & 3 \\
\hline \multicolumn{2}{|l|}{ Temperatura otoczenia $\left[{ }^{\circ} \mathrm{C}\right]$} & 23,8 & 23,8 & 23,8 \\
\hline \multirow{2}{*}{$\begin{array}{l}\text { Temperatura przed procesem } \\
\text { zgrzewania }\left[{ }^{\circ} \mathrm{C}\right]\end{array}$} & kształtka & 22,6 & 23,5 & 23,2 \\
\cline { 2 - 5 } & rura & 21,5 & 22,1 & 24,8 \\
\hline $\begin{array}{l}\text { Temperatura maksymalna } \\
\text { w trakcie zgrzewania }\left[{ }^{\circ} \mathrm{C}\right]\end{array}$ & kształtka & 170,0 & 160,0 & 147,0 \\
\cline { 2 - 5 } & rura & 119,7 & 107,8 & 104,0 \\
\hline \multicolumn{2}{|l|}{ Rzeczywista grubość ścianki rury $e_{n}[\mathrm{~mm}]$} & 6,0 & 6,0 & 6,0 \\
\hline
\end{tabular}

Tablica 6. Zestawienie temperatur $\mathrm{w}$ trakcie nagrzewania wstępnego od temperatury $-10^{\circ} \mathrm{C}$ do temperatury $0^{\circ} \mathrm{C}$ : mufa elektrooporowa $d_{n} 63$, SDR $11+\operatorname{rura} d_{n} 63, \operatorname{SDR} 11, e_{n} 5,8$

\begin{tabular}{|l|c|c|c|c|}
\hline \multicolumn{2}{|c|}{ Numery zgrzewu próbnego } & 1 & 2 & 3 \\
\hline \multirow{2}{*}{$\begin{array}{l}\text { Temperatura przed procesem } \\
\text { zgrzewania }\left[{ }^{\circ} \mathrm{C}\right]\end{array}$} & kształtka & $-8,8$ & $-9,6$ & $-8,9$ \\
\cline { 2 - 5 } & rura & $-10,0$ & $-10,0$ & $-10,0$ \\
\hline $\begin{array}{l}\text { Temperatura maksymalna w trak- } \\
\text { cie wstępnego nagrzewania }\left[{ }^{\circ} \mathrm{C}\right]\end{array}$ & kształtka & 4,1 & 13,3 & 13,9 \\
\cline { 2 - 5 } & rura & $-7,3$ & $-1,9$ & 1,3 \\
\hline Czas nagrzewania wstępnego $[\mathrm{s}]$ & & 26 & 50 & 60 \\
\hline Rzeczywista grubość ścianki rury $e_{n}[\mathrm{~mm}]$ & 6,0 & 5,9 & 6,0 \\
\hline
\end{tabular}

Tablica 7. Zestawienie temperatur $\mathrm{w}$ trakcie zgrzewania $\mathrm{w}$ temperaturze $-10^{\circ} \mathrm{C}$ : mufa elektrooporowa $d_{n} 63$, SDR $11+\operatorname{rura} d_{n} 63, \operatorname{SDR} 11, e_{n} 5,8$

\begin{tabular}{|c|c|c|c|c|}
\hline \multicolumn{2}{|c|}{ Numery zgrzewu próbnego } & 1 & 2 & 3 \\
\hline \multirow{2}{*}{$\begin{array}{l}\text { Temperatura przed procesem } \\
\text { zgrzewania }\left[{ }^{\circ} \mathrm{C}\right]\end{array}$} & kształtka & $-9,2$ & $-8,5$ & 9,0 \\
\hline & rura & $-10,0$ & $-10,0$ & $-9,5$ \\
\hline \multirow{2}{*}{$\begin{array}{l}\text { Temperatura maksymalna } \mathrm{w} \text { trak- } \\
\text { cie wstępnego nagrzewania }\left[{ }^{\circ} \mathrm{C}\right]\end{array}$} & kształtka & 16,5 & 16,5 & 14,3 \\
\hline & rura & 0,4 & $-1,4$ & 0,6 \\
\hline \multicolumn{2}{|l|}{ Czas nagrzewania wstępnego [s] } & 60 & 60 & 60 \\
\hline \multirow{2}{*}{$\begin{array}{l}\text { Temperatura maksymalna } \\
\text { w trakcie zgrzewania }\left[{ }^{\circ} \mathrm{C}\right]\end{array}$} & kształtka & 175,6 & 180,0 & 169,7 \\
\hline & rura & 98,7 & 109,5 & 112,3 \\
\hline \multicolumn{2}{|l|}{ Czas zgrzewania [s] } & 120 & 120 & 120 \\
\hline \multicolumn{2}{|c|}{ Rzeczywista grubość ścianki rury $e_{n}[\mathrm{~mm}]$} & 6,1 & 6,0 & 6,0 \\
\hline
\end{tabular}


W tym przypadku trudno jednoznacznie wskazać, czy temperatura w strefie zgrzewania była odpowiednia. Najbardziej wiarygodne byłyby pomiary temperatury wykonane bezpośrednio w strefie zgrzewania. Podobnie jak w poprzednim przypadku nie było to możliwe ze względu na możliwość zwarcia uzwojenia drutu oporowego kształtki czujnikiem temperatury. Analizując jednak wyniki pomiaru temperatury w rurze, można przypuszczać, że w celu uzyskania właściwej temperatury $\mathrm{w}$ strefie zgrzewania podczas procesu prowadzonego w temperaturze $-10^{\circ} \mathrm{C}$, podobnie jak w poprzednim przypadku, należałoby zwiększyć ilość dostarczanej energii do kształtki. Dodatkowo należy uwzględnić wydłużony czas nagrzewania wstępnego w stosunku do wartości obliczonej.

Doświadczalnie wyznaczono czas nagrzewania wstępnego równy $75 \mathrm{~s}$, to jest czas, dla którego osiągnięto dodatnie temperatury rury i kształtki.

Analizując wyniki pomiarów zrealizowanych kształtką $d_{n} 90 \mathrm{z}$ rurami SDR 17,6 (mniejsza grubość ścianki niż w przypadku rur w szeregu SDR 11), ze względu na znacznie odstające wyniki temperatury (tablica 8) dla próbki 1 i 2 w stosunku do wartości wskazanych w tablicy 8 zdecydowano, że zostaną one odrzucone. Powodem dużych różnic wartości temperatury kształtki w czasie zgrzewania $\mathrm{w}$ temperaturze $-10^{\circ} \mathrm{C}$ względem analogicznych wartości w temperaturze $23^{\circ} \mathrm{C}\left( \pm 2^{\circ} \mathrm{C}\right)$ mogło być niewłaściwe umiejscowienie czujników temperatury. Zmienność ich wyników odstaje również od prawidłowości w poprzednio rozważanych przypadkach.

Analiza przeprowadzona została więc na podstawie wyników uzyskanych dla próbki zgrzewu oznaczonej nr. 3 (tablica 10).

W pierwszej kolejności należy jednak zwrócić uwagę na otrzymane wyniki temperatury rury i kształtki w zgrzewach wykonanych w temperaturze $23^{\circ} \mathrm{C}\left( \pm 2^{\circ} \mathrm{C}\right)$ (tablica 8$)$. W tym przypadku, odwrotnie niż w poprzednich, wartości temperatury w rurze były wyższe niż w kształtce. Wynikało to zapewne z tego, że gdy czujnik temperatury został umiejscowiony w połowie grubości ścianki rury, znajdował się on znacznie bliżej uzwojenia drutu oporowego niż czujnik zlokalizowany w połowie grubości ścianki kształtki. Wynikało to natomiast z tego, że do zgrzewania wytypowano rurę w szeregu SDR 17,6, tj. o mniejszej grubości ścianki.

Mniejsza grubość ścianki ma również wpływ na czas nagrzewania wstępnego niezbędny do osiągnięcia dodatniej temperatury rury i kształtki. Obliczony wymagany czas nagrzewania wy- nosił $65 \mathrm{~s}$, natomiast dodatnią temperaturę kształtki i rury uzyskano dopiero po czasie $75 \mathrm{~s}$. W porównaniu z wynikami dla kształtki $d_{n} 90$ zgrzewanej z rurami SDR 11 wymagane było tutaj większe wydłużenie czasu nagrzewania. Wynika to zapewne $z$ tego samego powodu co w przypadku połączenia zgrzewanego $d_{n} 63$, ponieważ w obu przypadkach grubość materiału rury znajdującego się między powierzchnią czujnika temperatury a wewnętrzną powierzchnią rury, na którą oddziaływała bezpośrednio temperatura otoczenia, $\mathrm{tj} .-10^{\circ} \mathrm{C}$, była znacznie mniejsza niż dla przypadku kształtki $d_{n} 90$ i rury SDR 11. Powodowało to, że ciepło od rury było oddawane do otoczenia szybciej i czas do uzyskania temperatury rury powyżej $0^{\circ} \mathrm{C}$ musiał być dłuższy.

Tablica 8. Zestawienie wartości temperatur w trakcie zgrzewu W warunkach normalnych: $23^{\circ} \mathrm{C}\left( \pm 2^{\circ} \mathrm{C}\right)$, mufa elektrooporowa $d_{n} 90$, $\operatorname{SDR} 11+\operatorname{rura}_{n} 90, \operatorname{SDR} 17,6, e_{n} 5,2$

\begin{tabular}{|c|c|c|c|c|}
\hline \multicolumn{2}{|c|}{ Numery zgrzewu próbnego } & 1 & 2 & 3 \\
\hline \multicolumn{2}{|l|}{ Temperatura otoczenia $\left[{ }^{\circ} \mathrm{C}\right]$} & 23,8 & 23,8 & 23,8 \\
\hline \multirow{2}{*}{$\begin{array}{l}\text { Temperatura przed procesem } \\
\text { zgrzewania }\left[{ }^{\circ} \mathrm{C}\right]\end{array}$} & kształtka & 25,5 & 25,0 & 24,4 \\
\hline & rura & 23,5 & 23,5 & 23,0 \\
\hline \multirow{2}{*}{$\begin{array}{l}\text { Temperatura maksymalna } \\
\text { w trakcie zgrzewania }\left[{ }^{\circ} \mathrm{C}\right]\end{array}$} & kształtka & 124,0 & 139,0 & 127,5 \\
\hline & rura & 169,0 & 166,0 & 173,8 \\
\hline \multicolumn{2}{|c|}{ Rzeczywista grubość ścianki rury $e_{n}[\mathrm{~mm}]$} & 5,4 & 5,5 & 5,5 \\
\hline
\end{tabular}

Tablica 9. Zestawienie wartości temperatur w trakcie nagrzewania wstępnego od temperatury $-10^{\circ} \mathrm{C}$ do temperatury $0^{\circ} \mathrm{C}$ : mufa elektrooporowa $d_{n} 90+$ rura $d_{n} 90, \operatorname{SDR} 17,6, e_{n} 5,2$

\section{Numery zgrzewu próbnego}

\begin{tabular}{|c|c|c|c|c|}
\hline \multirow{2}{*}{$\begin{array}{l}\text { Temperatura przed procesem } \\
\text { zgrzewania }\left[{ }^{\circ} \mathrm{C}\right]\end{array}$} & kształtka & $-8,5$ & $-8,5$ & $-8,5$ \\
\hline & rura & $-10,0$ & 10,0 & $-10,0$ \\
\hline \multirow{2}{*}{$\begin{array}{l}\text { Temperatura maksymalna } \mathrm{w} \text { trak- } \\
\text { cie wstępnego nagrzewania }\left[{ }^{\circ} \mathrm{C}\right]\end{array}$} & kształtka & 9,6 & 11,2 & 12,3 \\
\hline & rura & $-2,0$ & $-1,93$ & 0,4 \\
\hline \multicolumn{2}{|l|}{ Czas nagrzewania wstępnego $[\mathrm{s}]$} & 65 & 70 & 75 \\
\hline \multicolumn{2}{|c|}{ Rzeczywista grubość ścianki rury $e_{n}[\mathrm{~mm}]$} & 5,2 & 5,3 & 5,4 \\
\hline
\end{tabular}

Tablica 10. Zestawienie temperatur w trakcie zgrzewania w temperaturze $-10^{\circ} \mathrm{C}$ : mufa elektrooporowa $d_{n} 90+$ rura $d_{n} 90$, SDR $17,6, e_{n} 5,2$

\begin{tabular}{|c|c|c|c|c|}
\hline \multicolumn{2}{|c|}{ Numery zgrzewu próbnego } & 1 & 2 & 3 \\
\hline \multirow{2}{*}{$\begin{array}{l}\text { Temperatura przed procesem } \\
\text { zgrzewania }\left[{ }^{\circ} \mathrm{C}\right]\end{array}$} & kształtka & $-9,2$ & $-9,0$ & $-8,5$ \\
\hline & rura & $-10,0$ & $-9,5$ & $-10,0$ \\
\hline \multirow{2}{*}{$\begin{array}{l}\text { Temperatura maksymalna w trak- } \\
\text { cie wstępnego nagrzewania }\left[{ }^{\circ} \mathrm{C}\right]\end{array}$} & kształtka & 16,5 & 16,5 & 12,5 \\
\hline & rura & 0,4 & $-1,4$ & 0,5 \\
\hline \multicolumn{2}{|l|}{ Czas nagrzewania wstępnego $[\mathrm{s}]$} & 75 & 75 & 75 \\
\hline \multirow{2}{*}{$\begin{array}{l}\text { Temperatura maksymalna } \\
\text { w trakcie zgrzewania }\left[{ }^{\circ} \mathrm{C}\right]\end{array}$} & kształtka & 175,6 & 180,0 & 135,6 \\
\hline & rura & 98,7 & 109,2 & 151,6 \\
\hline \multicolumn{2}{|l|}{ Czas zgrzewania $[\mathrm{s}]$} & 180 & 180 & 180 \\
\hline \multicolumn{2}{|c|}{ Rzeczywista grubość ścianki rury $e_{n}[\mathrm{~mm}]$} & 5,2 & 5,3 & 5,6 \\
\hline
\end{tabular}


Otrzymane wartości temperatury w czasie nagrzewania wstępnego przed właściwym procesem zgrzewania (tablica 10 , próbka nr 3) były zbieżne z wartościami uzyskanymi podczas ustalania właściwego czasu nagrzewania wstępnego (tablica 9). Znaczne różnice widoczne są natomiast dla wartości temperatury w rurze. Porównując wartości z tablicy $8, \mathrm{tj}$. $173^{\circ} \mathrm{C}$ (zgrzewanie w temperaturze $23^{\circ} \mathrm{C}\left( \pm 2^{\circ} \mathrm{C}\right)$ ), z wartością $\mathrm{z}$ tablicy $10, \mathrm{tj} .151,6^{\circ} \mathrm{C}$ (zgrzewanie $\mathrm{w}$ temperaturze $-10^{\circ} \mathrm{C}$ ), można stwierdzić, że - analogicznie do poprzednich przypadków - w celu uzyskania właściwej temperatury w strefie zgrzewania podczas procesu prowadzonego $\mathrm{w}$ temperaturze $-10^{\circ} \mathrm{C}$ należałoby zwiększyć ilość dostarczanej energii do kształtki. wstępnego nagrzewania uwzględniające SDR rur przedstawiono w tablicy 11.

Przy założonych parametrach wstępnego nagrzewania (tablica 11) i założonym napięciu $12 \mathrm{~V}$ oraz standardowych parametrach głównego procesu zgrzewania przy wykorzystaniu wytypowanych kształtek i rur PE wykonano zgrzewy elektrooporowe w temperaturze otoczenia $-10^{\circ} \mathrm{C}$.

Zgrzewy te poddano:

- ocenie wizualnej;

- badaniu wytrzymałości na:

- odporność na ciśnienie wewnętrzne - wytrzymałość hydrostatyczną $\left(80^{\circ} \mathrm{C}, 165 \mathrm{~h}\right)$,

- odporność na odrywanie $[9,11]$.

Wykonane badania miały potwierdzić jakość połączeń elektrooporowych i określić kryterium oceny jakości zgrzewów.

Ocenę wizualną złączy przeprowadzono po wykonaniu zgrzewu, przed badaniami niszczącymi, podczas przygotowania próbek do badań niszczących, jak również na każdym etapie badań niszczących. Badanie przeprowadzano nieuzbrojonym okiem $\mathrm{w}$ temperaturze $23^{\circ} \mathrm{C}\left( \pm 2^{\circ} \mathrm{C}\right)$. Wyniki z badań oceny wizualnej zgrzewów elektrooporowych przedstawiono w tablicy 12 .

Jak wynika z tablicy 12 , postawione wymagania dotyczące oceny wizualnej zostały speł-

\begin{tabular}{|c|c|c|c|}
\hline & Wymaganie do sprawdzenia & $\begin{array}{l}\text { Numer } \\
\text { zgrzewu }\end{array}$ & Wynik badania \\
\hline \multirow{7}{*}{ 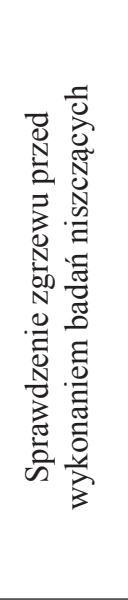 } & $\begin{array}{l}\text { Na całym obwodzie rury u nasady kształtki elektroopo- } \\
\text { rowej widoczne są ślady skrawania warstwy utlenionego } \\
\text { polietylenu. Warstwa utleniona jest usunięta równomier- } \\
\text { nie na całej powierzchni przeznaczonej do zgrzewania }\end{array}$ & \multirow{15}{*}{$\begin{array}{l}1,2,3 \\
4,5,6 \\
7,8,9 \\
10\end{array}$} & pozytywny \\
\hline & $\begin{array}{l}\text { Uzwojenie drutu oporowego nie wysunęło się poza ob- } \\
\text { rys kształtki }\end{array}$ & & pozytywny \\
\hline & $\begin{array}{l}\text { Położenie wskaźników zgrzewania jest zgodne z opisem } \\
\text { zawartym w instrukcji producenta kształtki }\end{array}$ & & pozytywny \\
\hline & $\begin{array}{l}\text { Powierzchnia kształtki nie wykazuje żadnych odkształceń } \\
\text { powstałych w wyniku nagrzewania }\end{array}$ & & pozytywny \\
\hline & Wady zgrzewu: & & brak/pozytywny \\
\hline & - wypływ tworzywa poza obrys kształtki & & brak/pozytywny \\
\hline & - jednostronny brak zgrzeiny & & brak/pozytywny \\
\hline \multirow{5}{*}{ 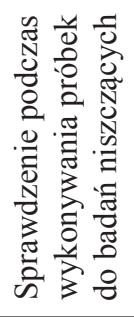 } & $\begin{array}{l}\text { Powierzchnia kształtki nie wykazuje żadnych odkształ- } \\
\text { ceń powstałych w wyniku nagrzewania }\end{array}$ & & pozytywny \\
\hline & Wady zgrzewu: & & brak/pozytywny \\
\hline & - przemieszczenie uzwojenia drutu oporowego & & brak/pozytywny \\
\hline & - jednostronny brak zgrzeiny & & brak/pozytywny \\
\hline & - niewłaściwe posadowienie rur w kształtce & & brak/pozytywny \\
\hline \multirow{3}{*}{ 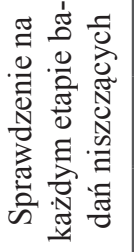 } & Wady zgrzewu: & & brak/pozytywny \\
\hline & - przemieszczenie uzwojenia drutu oporowego & & brak/pozytywny \\
\hline & - jednostronny brak zgrzeiny & & brak/pozytywny \\
\hline
\end{tabular}

nione dla wszystkich zgrzewów przed wykonaniem badań niszczących, podczas wykonywania próbek do badań niszczących, jak również na każdym etapie badań niszczących. Uzyskano pozytywne wyniki badania, które potwierdzają poprawność wykonania zgrzewu.

Z wykonanych zgrzewów elektrooporowych, przy założonych parametrach nagrzewania wstępnego i zgrzewania głównego, przygotowano próbki, na których przeprowadzono badanie wytrzymałości hydrostatycznej, zgodnie z PN-EN ISO 1167-1:2007 [8], w temperaturze $80^{\circ} \mathrm{C}$ i naprężeniu obwodowym 5,4 MPa. Wyniki z dokonanych badań wytrzymałości hydrostatycznej przedstawiono w tablicy 13 .

Tablica 11. Wyznaczone doświadczalnie czasy wstępnego nagrzewania

\begin{tabular}{|c|c|c|c|c|c|}
\hline \multicolumn{2}{|c|}{ Kształtka PE } & \multicolumn{2}{|c|}{ Rura } & \multirow{2}{*}{$\begin{array}{c}\text { Napięcie } \\
\text { wstępnego } \\
\text { nagrzewania }\end{array}$} & \multirow{2}{*}{$\begin{array}{c}\text { Czas } \\
\text { nagrzewania } \\
\text { wstępnego }\end{array}$} \\
\hline $\begin{array}{c}\text { średnica } \\
\text { zewnętrzna } d_{n}\end{array}$ & SDR & $\begin{array}{l}\text { grubość } \\
\text { ścianki } e_{n}\end{array}$ & SDR & & \\
\hline$[\mathrm{mm}]$ & & {$[\mathrm{mm}]$} & & [V] & {$[\mathrm{s}]$} \\
\hline 63 & 11 & 5,8 & 11 & 12 & 60 \\
\hline 90 & 11 & 8,2 & 11 & 12 & 80 \\
\hline 90 & 11 & 5,2 & 17,6 & 12 & 75 \\
\hline
\end{tabular}

Tablica 12. Zestawienie wyników oceny wizualnej 
W czasie 165 godzin próbki wykazały brak pęknięć i nieszczelności. Testy wytrzymałościowe połączeń potwierdzają odpowiednią jakość połączenia rury z kształtką. Jak wynika z tablicy 13 , postawione wymagania zostały spełnione dla wszystkich próbek - uzyskano pozytywne wyniki badania.

Wyniki z przeprowadzonych badań odporności na odrywanie zgrzewów elektrooporowych według normy ISO 13955:1997 [6] przedstawiono w tablicy 14 .

Po zaciśnięciu oderwanie nie wystąpiło na długości większej niż oderwanie dopuszczalne, czyli na długości mniejszej niż 1/3 długości strefy grzania dla każdej badanej próbki. Postawione wymagania dotyczące odporności na odrywanie zostały spełnione dla wszystkich próbek - uzyskano pozytywne wyniki badania.

Jak wynika z tablicy 14 , próbę można uznać za pozytywną, jeżeli postawione wymagania odporności na odrywanie zgrzewów zostały spełnione dla wszystkich próbek.

Analizując pozytywne wyniki badań wizualnych i wytrzymałościowych połączeń zgrzewanych wykonanych w temperaturze $-10^{\circ} \mathrm{C}$, przy wyznaczonych doświadczalnie warunkach i parametrach, należy stwierdzić, że wykonywanie połączeń zgrzewanych w temperaturach ujemnych jest możliwe.

Niemniej jednak wartości czasów nagrzewania wstępnego ustalone zostały doświadczalnie i indywidualnie dla
Tablica 13. Zestawienie wyników badań wytrzymałości hydrostatycznej

\begin{tabular}{|c|c|c|c|c|c|c|}
\hline \multicolumn{3}{|c|}{ Próbka } & \multicolumn{2}{|c|}{ Parametry badania } & \multirow{2}{*}{\multicolumn{2}{|c|}{$\begin{array}{c}\text { Wyniki badania } \\
\text { uzyskane }\end{array}$}} \\
\hline \multirow{3}{*}{$\begin{array}{c}\text { numer } \\
\text { zgrzewu }\end{array}$} & \multirow{3}{*}{ kształtka } & \multirow{3}{*}{ rura } & \multirow{3}{*}{$\begin{array}{l}\text { ciśnienie } \\
\text { badania }\end{array}$} & \multirow{2}{*}{$\begin{array}{c}\text { czas do } \\
\text { uszkodzenia }\end{array}$} & & \\
\hline & & & & & $\begin{array}{c}\text { czas } \\
\text { badania }\end{array}$ & \multirow{2}{*}{$\begin{array}{c}\text { typ } \\
\text { zniszczenia }\end{array}$} \\
\hline & & & & [godz.] & [godz.] & \\
\hline 1 & 63, SDR 11, PE 100 & SDR 11, PE 100 & $1,16 \mathrm{MPa}$ & 165 & $>165$ & brak \\
\hline 2 & 63, SDR 11, PE 100 & SDR 11, PE 100 & $1,16 \mathrm{MPa}$ & 165 & $>165$ & brak \\
\hline 5 & 90, SDR 11, PE 100 & SDR 11, PE 100 & $1,13 \mathrm{MPa}$ & 165 & $>165$ & brak \\
\hline 6 & 90, SDR 11, PE 100 & SDR 11, PE 100 & $1,13 \mathrm{MPa}$ & 165 & $>165$ & brak \\
\hline 9 & 90, SDR 11, PE 100 & SDR 17,6, PE 100 & $0,7 \mathrm{MPa}$ & 165 & $>165$ & brak \\
\hline
\end{tabular}

Tablica 14. Zestawienie wyników badań odporności na odrywanie

\begin{tabular}{|c|c|c|c|c|c|c|c|}
\hline \multicolumn{5}{|c|}{ Próbka } & \multicolumn{3}{|c|}{ Wyniki } \\
\hline \multirow[t]{2}{*}{$\begin{array}{c}\text { numer } \\
\text { zgrzewu }\end{array}$} & \multirow{2}{*}{$\begin{array}{c}\text { średnica } \\
\text { nominalna } \\
\text { kształtki } d_{n}\end{array}$} & \multirow{2}{*}{$\begin{array}{l}\text { średnica } \\
\text { nominalna } \\
\text { rury } d_{n}\end{array}$} & \multirow[t]{2}{*}{$\begin{array}{l}\text { SDR } \\
\text { rury }\end{array}$} & \multirow{2}{*}{$\begin{array}{l}\text { długość } \\
\text { strefy } \\
\text { grzania } \mathrm{L}_{2}\end{array}$} & $\begin{array}{c}\text { wymagana } \\
\text { długość strefy } \\
\text { pękania } \leq \mathrm{L}_{2} / 3\end{array}$ & \multirow{2}{*}{$\begin{array}{c}\text { uzyskana } \\
\text { długość } \\
\text { pęknięcia }\end{array}$} & \multirow[t]{2}{*}{$\begin{array}{l}\text { stwierdzenie } \\
\text { zgodności }\end{array}$} \\
\hline & & & & & {$[\mathrm{mm}]$} & & \\
\hline \multirow{4}{*}{3} & \multirow{4}{*}{63} & \multirow{4}{*}{63} & \multirow{4}{*}{11} & \multirow{4}{*}{24} & \multirow{4}{*}{$\leq 8$} & 2,2 & \multirow{4}{*}{ pozytywny } \\
\hline & & & & & & 2,2 & \\
\hline & & & & & & 2,0 & \\
\hline & & & & & & 1,6 & \\
\hline \multirow{4}{*}{4} & \multirow{4}{*}{63} & \multirow{4}{*}{63} & \multirow{4}{*}{11} & \multirow{4}{*}{24} & \multirow{4}{*}{$\leq 8$} & 2,0 & \multirow{4}{*}{ pozytywny } \\
\hline & & & & & & 2,1 & \\
\hline & & & & & & 1,7 & \\
\hline & & & & & & 1,6 & \\
\hline \multirow{8}{*}{7} & \multirow{8}{*}{90} & \multirow{8}{*}{90} & \multirow{8}{*}{11} & \multirow{8}{*}{35} & & 3,1 & \\
\hline & & & & & & 3,5 & \\
\hline & & & & & & 3,1 & \\
\hline & & & & & & 3,0 & \\
\hline & & & & & $\leq 11,3$ & 2,9 & pozytywny \\
\hline & & & & & & 2,5 & \\
\hline & & & & & & 2,0 & \\
\hline & & & & & & 2,0 & \\
\hline & & & & & & 2,2 & \\
\hline & & & & & & 2,6 & \\
\hline & & & & & & 1,9 & \\
\hline & & & & & & 3,0 & \\
\hline 8 & 90 & 90 & 11 & 35 & $\leq 11,3$ & 2,6 & pozytywny \\
\hline & & & & & & 24 & \\
\hline & & & & & & 2,8 & \\
\hline & & & & & & 2,7 & \\
\hline & & & & & & 2,2 & \\
\hline & & & & & & 1,8 & \\
\hline & & & & & & 2,9 & \\
\hline 10 & 90 & 90 & 176 & 35 & $<113$ & 2,6 & nozytywny \\
\hline 10 & 90 & 90 & $1 /, 0$ & 35 & $\leq 11,3$ & 3,0 & pozylywny \\
\hline & & & & & & 2,7 & \\
\hline & & & & & & 3,1 & \\
\hline & & & & & & 3,2 & \\
\hline
\end{tabular}

danego typu kształtki i rodzaju rury (szereg wymiarowy SDR). Nie daje to podstawy do opracowania procedury, na podstawie której możliwe byłoby wykonywanie połączeń 
zgrzewanych w temperaturach ujemnych dla wszystkich kształtek o różnych średnicach i grubościach ścianek. Uzyskane wyniki wskazują jednak, że opracowanie takiej procedury możliwe jest na podstawie modelu uwzględniającego nieustalony charakter zmian temperatury w czasie, jak również całkowitą grubość zgrzewanych rur, która w zasadniczy sposób wpływa na jego wartość oraz wielkości luzu pomiędzy rurą i kształtką. Zdobyta podczas realizacji pracy wiedza może stanowić duży wkład do ostatecznego opracowania procedur zgrzewania elektrooporowego w temperaturach ujemnych.

\section{Wnioski końcowe}

W ramach pracy opracowano metodykę zgrzewania elektrooporowego w ujemnych temperaturach otoczenia, która uwzględnia ustalenie parametrów wstępnego nagrzewania poprzez zastosowanie obniżonego napięcia zgrzewania w określonym czasie. Proces ten miał powodować uzyskanie dodatniej temperatury kształtki i rury, tak aby można było rozpoczać właściwy proces zgrzewania. Opracowaną metodykę zweryfikowano doświadczalnie. Na podstawie otrzymanych wyników i ich analizy stwierdzono, że nie umożliwia ona opracowania uniwersalnej procedury, na podstawie której możliwe byłoby wykonywanie połączeń zgrzewanych w temperaturach ujemnych w terenie w sytuacjach awaryjnych. Możliwe jest natomiast ustalenie parametrów prowadzenia procesu nagrzewania wstępnego i właściwego zgrzewania w sposób doświadczalny, indywidualnie dla danego rodzaju kształtki.

W przeprowadzonych badaniach nie uzyskano powtarzalnych wyników, na podstawie których można by opracować uniwersalną procedurę zgrzewania dla pełnego asortymentu (wszystkich rodzajów i wielkości) kształtek i rur PE w temperaturach ujemnych w terenie, w sytuacjach awaryjnych.

Otrzymane wyniki pokazują, że przed rozpoczęciem procesu zgrzewania w temperaturach ujemnych możliwe jest ogrzanie kształtki i rur do temperatury dodatniej poprzez zastosowanie nagrzewania wstępnego przy obniżonym, w stosunku do podanego przez producenta, napięciu zgrzewania. Na obecną chwilę ustalenie parametrów tego procesu może się odbywać jednak w sposób doświadczalny w warunkach laboratoryjnych, indywidualnie dla danego rodzaju kształtki.

$\mathrm{Na}$ podstawie zebranych doświadczeń w ramach realizacji pracy wskazano na dodatkowe obszary, które należałoby uwzględnić przy opracowywaniu procedury zgrzewania elektrooporowego w ujemnych temperaturach otoczenia. Opracowanie procedury wymaga jednak dodatkowych badań, które powinny obejmować zróżnicowane wielkości i asortyment kształtek.

Prosimy cytować jako: Nafta-Gaz 2018, nr 7, s. 552-559, DOI: 10.18668/NG.2018.07.09

Artykuł nadesłano do Redakcji 24.11.2017 r. Zatwierdzono do druku 21.05.2018 r.

Artykuł powstał na podstawie pracy statutowej pt.: Opracowanie procedur zgrzewania elektrooporowego rur PE w temperaturach ujemnych - praca INiG - PIB na zlecenie MNiSW; nr zlecenia 0077/GP/01, nr archiwalny DK-4100-64/17.

\section{Literatura}

[1] Klupa A., Szewczyk P.: Wptyw zamykania przeptywu metoda zaciskania na wytrzymałość hydrostatyczna gazociagów polietylenowych. Nafta-Gaz 2009, nr 3, s. 243-247.

[2] Szewczyk P.: Badania odporności na oddziaływania punktowe rur polietylenowych warstwowych uktadanych $w$ gruncie rodzimym, przeznaczonych do przesytania gazu. Nafta-Gaz 2012, nr 9, s. 611-616.

[3] Szewczyk P.: Nowoczesne materiaty i technologie do budowy gazociagów wysokiego ciśnienia oraz rurociagów technologicznych na terenach górniczych. Nafta-Gaz 2017, nr 10, s. 778-783, DOI:10.18668/NG.2017.10.07.

\section{Akty prawne i normatywne}

[4] Rozporządzenie Ministra Gospodarki z dnia 26 kwietnia 2013 roku w sprawie warunków technicznych, jakim powinny odpowiadać sieci gazowe i ich usytuowanie (Dz.U. z 2013 r. poz. 640).

[5] PN-EN 12524:2003 Materiaty $i$ wyroby budowlane. Właściwości cieplno-wilgotnościowe. Tabelaryczne wartości obliczeniowe.

[6] ISO 13955:1997 Plastics pipes and fittings. Crushing decohesion test for polyethylene (PE) electrofusion assemblies.

[7] ST-IGG-1901:2016 Standard Techniczny. Kontrola połaczeń zgrzewanych doczołowo i elektrooporowo przy budowie gazociagów z polietylenu. Wymagania i zalecenia.
[8] PN-EN ISO 1167-1:2007 Rury, ksztaltki i zestawy z termoplastycznych tworzyw sztucznych do przesyłania płynów. Oznaczanie wytrzymałości na ciśnienie wewnętrzne. Część 1: Metoda ogólna.

[9] PN-EN 1555-2:2012 Systemy przewodów rurowych z tworzyw sztucznych do przesylania paliw gazowych. Polietylen (PE). Czesść 5: Przydatność systemu do stosowania.

[10] PN-EN 12007-2:2013-02 Infrastruktura gazowa. Rurociagi o maksymalnym ciśnieniu roboczym do 16 bar włacznie. Część 2: Szczególowe wymagania funkcjonalne dotyczace polietylenu (MOP do 10 bar wtacznie).

[11] PN-EN 1555-3 + A1:2013-05 Systemy przewodów rurowych z tworzyw sztucznych do przesytania paliw gazowych. Polietylen (PE). Część 3: Ksztattki.

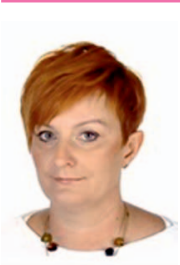

Mgr inż. Anna WRÓBLEWSKA

Starszy specjalista badawczo-techniczny w Zakładzie Przesyłania i Dystrybucji Gazu - Laboratorium Tworzyw Sztucznych.

Instytut Nafty i Gazu - Państwowy Instytut Badawczy ul. Lubicz 25 A, 31-503 Kraków

E-mail: anna.wroblewska@inig.pl 